\title{
The Effect of Implementing Rhythmic Gymnastics to Improve Motor Skills of Primary School Students
}

\author{
S G Handayani
}

\author{
Faculty of Sport Science, Universitas Negeri Padang, Indonesia \\ *Corresponding author. Email: handayanisrigusti@gmail.com
}

\begin{abstract}
The aim of this study is to determine the effect of rhythmic gymnastics training towards improvement of motor skills among elementary school students of Laboratorium Pembangunan Universitas Negeri Padang. A quasi-experimental research using pretest-posttest group design with one independent variable and one dependent variable. The independent variable is the rhythmic gymnastics activities, while the dependent variable is the motor ability of the students. The research design used was Pretest-Posttest Group Design using One independent variable, and one dependent variable. The independent variable is rhythmic exercise, while the dependent variable is Motor skill. Based on the analysis of data and discussion, it can be concluded that the implementation of rhythmic gymnastics gave significant effect to the improvement of students' motor skill which can be seen where observed $=8.93>$ ttab $=1.76$.
\end{abstract}

\section{Keywords: Rhythmic gymnastics, motor skills, primary school students}

\section{INTRODUCTION}

Physical exercise has become part of everyday activities which is important and a necessity for human beings to form physical and spiritual healthiness. It is proved that no matter as densely as any activity done by people but they are still available to do sports activities. The development of sports nowadays has made a positive and tangible contribution to the improvement of fitness, freshness and public health. One of the positive side of sport is that it can bring the name of the nation in International event. In addition, sports also play a major role in the formation of attitudes that will impact on the character of the nation. One of the familiar sports is rhythmic gymnastics. Rhythmic gymnastics is a movement done beautifully accompanied by music. Beside creating physical fitness, this gymnastics is also a branch of sports achievements that have been contested from the regional level to the National or International levels.

Rhythmic gymnastics very demands high flexibility compared to other sports. Therefore, rythmic gymnastics training should be implemented from an early age. Such training can be done in primary schools because it is stated in the curriculum that there is Rhythmic Gymnastics in primary school. With the existence of rhythmic gymnastics in primary school, it is expected that it can improve the motor skill of students. The problems that occur is how to provide rhythmic gymnastics at school in Penjasorkes subject to improve motor skills of students. This is because one of the factors that determine the success in teaching is the existing learning implementation plan, in which based on the observation, has not been in accordance with the desired goals. Moreover, the object trained is a child with different levels of understanding about motion.

One way that can be used to train the motor skill of elementary school students is by applying rhythmic gymnastics. This rhythmic gymnastics can improve the motor skills of the children. Motor ability/skill is the children's ability to move or make a motion. A child's physical development will directly determine his/her skill to perform a motion, while growth and physical development indirectly will affect how the child views his/her own ability.

Physical development closely related to motor development is the development of physical movement control through the activities of the central nervous system, nerves and coordinated muscles. Children have two components of motor skills that needed to be developed, namely rough/gross motor skill and fine motor skill. Rough Motor skill is a movement performed by large muscles activities such as: walking straight, walking following a winding pattern, walking sideways, running straight, running following winding patterns, jumping on two legs, and jumping over obstacles. Whereas Fine Motor Skill is a movement performed by small muscles activities such as: cutting, sticking, mtearing, composing the beam into a representative form, drawing, coloring, and writing (Petterson, 1996).

Each childrin has different abilities. There are children who have good motor skills and there are not. For those who are less able to perform rough motor skill such as locomotor movement, nonlokomotor 
movement, and manipulative movements, can be given such exercises such as jumping, climbing, running, walking. While for children who have not been able to perform fine motor activities, can be given such exercises like folding, shaping, and so forth. The general difference between gross and fine motor skill can be seen in its coordination and biomechanics. Rough motor skills are important to develop because, in line with the development of gross motor skills, it will also play a role in developing other children's abilities such as physiological development, socio-emotional development, and cognitive development. Development of students' motor skills in elementary school, is expected to adjust the curriculum and the factors that influence it. Thus, the development of students' motor skills will be more easily upgraded. Besides, in terms of achieving one of the objectives of elementary education that is to develop skills, it will be easier to implement children's creativity and abilities (Komaini, 2017).

Sekolah Dasar Laboratorium Pembangunan Universitas Negeri Padang is one of the elementary Schools located in Padang under the auspices of Universitas Negeri Padang. SD Pembangunan also enrolls the curriculum of Physical Education health and recreation, which one of its goals is to develop motor skills. Based on the author's observation in the field, it is known that there are still many elementary students who still have low motor skills, this is proved by the quality of movement shown at Penjasorkes subject. Some students still performed rough and unfavorable movement which obstructs the achievement of physical fitness. This condition calls for a solution immediately. One of the solutions that can be given is to provide a rhythmic gymnastics exercise, so that the students are motivated with gym movements and can improve motor skills and physical fitness. For this reason, the researcher conducted a study entitled The Effect of Implementing Rythmic Gymnastics To Improve Motor Skills of Primary School Students

\section{METHOD}

The research design used was Pretest-Posttest Group Design using One independent variable, and one dependent variable. The independent variable was rhythmic gymnastics, while the dependent variable was motor skill. The type of research used in this study was experimental design. The research was conducted at SD Laboratorium Pembangunan UNP. The population in this study was all students of that school which amounted to 191 students. Samples were taken by purposive sampling technique, so that there were 35 students taken as samples. The instruments used to measure motor skills are motor skills test for students (Gusril, 2008: 202). The purpose of the instrument is to measure general motor skills possessed by students and at the same time to classify students in the classroom.
The type of test were: 1) Basketball throw, 2) $4 \mathrm{sec}$ dash, 3) Passing ball (Wall Pass), 4) Broad jump.

\section{RESULT AND DISCUSSION}

The hypothesis of this study was tested by using ttest analysis. Before the t-test is conducted, the normality test is firstly conducted to determine whether the data was normally distributed or not.

\section{Normality test}

Normality test of initial data distribution (pre test) and final test (post test) of students' basic motor ability were analyzed by statistic test of Lilliefors with level of significance is $\alpha=0,05$. The summary of Lilliefors Normality test RESULTS is shown in the following table: 1

Table 1. Summary of Normality Test results

\begin{tabular}{|c|c|c|c|c|c|}
\hline \multirow{2}{*}{$\mathrm{N}$} & \multicolumn{2}{|c|}{ Pretest } & \multicolumn{2}{c|}{ Posttest } & \multirow{2}{*}{ Ket } \\
\cline { 2 - 5 } & $\mathrm{L}_{\mathrm{O}}$ & $\mathrm{L}_{\text {table }}$ & Lo & L $_{\text {table }}$ & \\
\hline 18 & 0.1536 & 0.2200 & 0.1734 & 0.2200 & Normal \\
\hline
\end{tabular}

Based on the table above, it can be seen that both tests obtained Lo <Lt, so it can be concluded that the sample group was distributed normally.

The data was analyzed by calculating the influence of rhythmic gymnastics development model on the students' basic motor ability. The statistical test used was t-test to see the effect of the average count in the same group at the 0.05 significance level where the results of the analysis show that:

Table 2. Summary of Hypothesis Testing results

\begin{tabular}{|c|c|c|c|}
\hline Variables & $\mathbf{N}$ & $\mathbf{T}_{\mathbf{o b s}}$ & $\mathbf{t}_{\text {tab }}$ \\
\hline $\begin{array}{c}\text { Students' Basic Motor } \\
\text { Capability }\end{array}$ & 18 & 8.93 & 1.76 \\
\hline
\end{tabular}

Based on the analysis results in the table above, it can be seen that Ho is rejected and $\mathrm{Ha}$ is accepted. It was showed that $t_{\text {observed }}=8.93>t_{\text {table }}=1.76$. Thus, it can be concluded that the development of rhythmic gymnastics model gives a significant influence towards students' basic motor skill ability.

Based on the result of hypothesis testing, $\mathrm{t}_{\mathrm{observed}}$ was 8.93 which is higher than $(>) t_{\text {table }}(1.76)$ at significance level $\alpha=0,05$. Thus, it can be concluded that Ho is rejected and $\mathrm{Ha}$ is accepted. Thus, the implementation of rhythmic gymnastic training gives a significant influence towards the students' basic motor ability in elementary school.

Motor ability is the ability of someone's performance who is influenced by the factors of strength, speed, endurance and coordination, thereby making it is easier to perform motion skills. Motor development in elementary school students includes the development of gross and fine motor skills. Children 
motor development will be more optimized if the environment where children growth supports them to move freely. Outdoor activities can be the best choice because it can stimulate muscle development. If the child's activities are in the room, maximizing the room can be used as a strategy to provide free space for children to run, jump and move their entire body in unlimited ways.

One form of exercise to develop a child's motor skill is to perform a variety of sports movement, one of them is a rhythmic gymnastic activity. Rhythmic activity is a series of human motion performed in the bond pattern and rhythm within time or only body expression following the music or power outside the music. That is the reason why rhythmic gymnastics that had been even said as a kind of dance.

Rhythmic gymnastic should be mastered by children to make a move containing body movements. The basic motions based on its difficulties factors includes jumps or leaps, balances, pivots, flexibility and waves. In practice, basic materials will be provided with the help of media presented in separate sections. And therefore, it takes a video to present the training materials in different ways. For example in the blow material, the video is presented in elements, ranging from racket swing while impact and follow trought are presented separately.

Thus, the development of the rhythmic exercise model is a form of development of rhythmic gymnastics by using various means so that gymnastics can be more fun for children. It is intended in order to the material can be conveyed well to the students so the students understand the material given, which indirectly the students will participate in various gymnastics movements as well. So the basic motor skills of students can increase better. Finally based on the provision of statistical tests, it was concluded that the application of rhythmic gymnastics has a significant effect on the improvement of motor skills of elementary school students.

\section{CONCLUSION}

Based on the analysis of data and discussion, it can be concluded that the implementation of rhythmic gymnastics exercise gives a significant effect on the improvement of motor ability of Primary School Students, this can be seen $\mathrm{t}_{\text {observed }}=8.93>\mathrm{t}_{\text {table }}=1.76$.

\section{REFERENCES}

[1] Agus Irianto. 2006. Statistik Konsep Dasar dan Aplikasinya. Cetakan ke-3. Jakarta: Kencana.

[2] Agus Mahendra. (2001). Buku III Materi Pelatihan Guru Pendidikan Jasmani dan Kesehatan SD/Pelatih Klub Olahraga Usia Dini SD. Jakarta: Departemen Pendidikan Nasional.
[3] A, Komaini, Fundamental Motor Skills of Kindergarten Students (A Survey Study of the Influence of Financial Condition, Playing Activity, and Nutritional Status). IOP Publishing. IOP Conf. Series: Materials Science

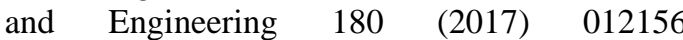
doi:10.1088/1757-899X/180/1/012156

[4] FIG (2005). Code of Points Rhythmic Gymnastics

[5] Gusril. 2008. Perkembangan Motorik Pada Masa Anak-Anak. Padang: UNP Press.

[6] Hirlock. 1993. Perkembangan Anak . Jakarta: Erlangga.

[7] Kiram, Yanuar. 1992. Belajar Motorik. Jakarta: Departemen Pendidikan dan Kebudayaan.

[8] Lutan, Rusli. 1998. Belajar Keterampilan Motorik, Pengantar Teori dan Motorik. Jakarta: Departemen Pendidikan Nasional.

[9] Nadejda Jastrjembskaia, Yun Titov (1999) Rhythmic Gymnastics International. FIG

[10] Petterson. 1996. Hubungan tingkat pengetahuan ibu tentang stimulasi dengan perkembangan motorik dasar anak usia 3-5 tahun di serdan.

[11] Sujiono, Bambang., dkk. 2005. Metode Pengembangan Fisik. Universitas Terbuka. 